回回回回回回回回回回回回回回回回回回回回回回回

Problemy istorii, filologii, kul'tury

1 (2020), 164-174

(C) The Author(s) 2020

Проблемы истории, филологии, культуры 1 (2020), 164-174

(с)Автор(ы) 2020

DOI: $10.18503 / 1992-0431-2020-1-67-164-174$

\author{
ПИСЬМА А.А. БОБРИНСКОГО, К.Е. ДУМБЕРГА \\ И В.В. ШКОРПИЛА К В.В. ЛАТЫШЕВУ \\ (В САНКТ-ПЕТЕРБУРГСКОМ ФИЛИАЛЕ АРХИВА РАН)
}

\begin{abstract}
Е.Г. Застрожнова
Санкт-Петербургский филиал Архива РАН, Санкт-Петербург, Россия pankratova0484@yandex.ru
\end{abstract}

Аннотаиия. В статье представлены письма председателя Императорской археологической комиссии А.А. Бобринского и директоров Керченского музея древностей К.Е. Думберга и В.В. Шкорпила, направленные В.В. Латышеву и касающиеся различных вопросов открытия, приобретения, интерпретации и изучения эпиграфических памятников, найденных на юге Российской империи в 1892-1910 гг. Благодаря анализу такого ценного архивного источника, как эпистолярное наследие ученых, становится возможным установить неизвестные ранее подробности организации и проведения археологических раскопок на территории Северного Причерноморья, проследить источники пополнения археологических коллекций, а также выявить особенности исследовательской и методической работы с такой категорией археологических находок, как эпиграфические памятники и керамические клейма.

Ключевые слова: эпиграфика, Боспорское царство, история археологического изучения, В.В. Латышев, история науки, архивные документы

В условиях интенсивно развивающейся истории отечественной археологии для комплексного понимания личности ученых крайне важно исследование не только научного, но и эпистолярного наследия, поскольку изучение системы научных коммуникаций позволяет установить взаимосвязи между наукой и властью, наукой и обществом, а также взаимодействие ученых внутри собственной, научной и личной, коммуникативной сети. Переписка выдающегося антиковеда и эпиграфиста, академика Российской Академии наук В.В. Латышева (1855-1921) до настоящего времени в полном объеме не публиковалась, в научных исследованиях по истории изучения Северного Причерноморья приводятся лишь цитаты из его писем. Между тем научная работа с комплексом этих архивных материалов позволит выявить неизвестные ранее подробности организации и проведения

\footnotetext{
Данные об авторе: Застрожнова Евгения Григорьевна - кандидат исторических наук, заведующая отделом обработки, комплектования и ведомственных архивов СПбФ АРАН.

Исследование проведено при финансовой поддержке гранта РФФИ № 18-09-40115 «Научные коммуникации в отечественной археологической науке во второй половине 19 - первой четверти 20 вв. (на основе неопубликованных архивных источников)».
} 
археологических раскопок на юге России, источники пополнения археологических коллекций, а также подробности исследовательской и методической работы с такой категорией археологических находок, как эпиграфические памятники и керамические клейма.

В фонде В.В. Латышева, хранящемся в Санкт-Петербургском филиале Архива РАН под № 110, переписка ученого выделена в опись № 2 и включает в себя 71 единицу хранения за 1887-1919 гг. Среди многочисленных корреспондентов В.В. Латышева следует отметить историка-византиниста В.Н. Бенешевича ${ }^{1}$, apхеолога и нумизмата А.Л. Бертье-Деларгарда ${ }^{2}$, филолога-классика Б.В. Варнеке ${ }^{3}$, историка и археографа В.Г. Дружинина ${ }^{4}$, археолога, директора Херсонесского музея древностей К.К. Косцюшко-Валюжнича ${ }^{5}$, филолога-слависта П.А. Лаврова $^{6}$, археолога-антиковеда Б.Ф. Фармаковского. В данной работе будут рассмотрены письма В.В. Латышеву от председателя Императорской археологической комиссии (ИАК) А.А. Бобринского ${ }^{7}$ и директоров Керченского музея древностей К.Е. Думберга ${ }^{8}$ и В.В. Шкорпила ${ }^{9}$. Письма этих корреспондентов укладываются примерно в один хронологический отрезок - 1890-1910 гг., что позволяет проанализировать уровень развития античной археологии в Российской империи на рубеже столетий.

С именем последнего председателя ИАК - графа Алексея Александровича Бобринского ${ }^{10}$ - связана деятельность Комиссии по охране, реставрации и научному изучению историко-археологических памятников по на всей территории страны, а меры, предпринятые Комиссией под его руководством, положили начало формированию единой централизованной системы археологических исследований ${ }^{11}$. В.В. Латышев, будучи к концу XIX в. широко известным специалистом в области античной эпиграфики и истории античности, входил в состав Императорского Русского (ИРАО) и Московского археологических обществ (МАО) и состоял членом-корреспондентом ИАК с июля 1892 г. По поручению ИРАО В.В. Латышев неоднократно совершал поездки по античным памятникам юга России с целью

\footnotetext{
1 СПбФ АРАН. Ф. 110. Оп. 2. Д. 2.

2 СПбФ АРАН. Ф. 110. Оп. 2. Д. 4.

3 СПбФ АРАН. Ф. 110. ОП. 2. Д. 10.

4 СПбФ АРАН. Ф. 110. ОП. 2. Д. 17.

5 СПбФ АРАН. Ф. 110. Оп. 2. Д. 23.

6 СПбФ АРАН. Ф. 110. ОП. 2. Д. 25.

7 СПбФ АРАН. Ф. 110. ОП. 2. Д. 5.

8 СПбФ АРАН. Ф. 110. ОП. 2. Д. 19.

9 СПбФ АРАН. Ф. 110. Оп. 2. Д. 66.

10 Бобринский (Бобринской) Алексей Александрович, (1852-1927), граф, общественный и политический деятель, историк, археолог; действительный (1882) и почетный (1894) член, управляющий Русским отделением (1885-1894) РАО, член-корреспондент (1882), действительный член (1904) $\mathrm{MAO}$, иностранный член-корреспондент Шведской королевской академии литературы, истории и древностей; член Комитета для изучения Средней и Восточной Азии, член многих иностранных и русских археологических обществ и архивных комиссий. Председатель Императорской Археологической комиссии (1886-1918), провел раскопки около одной тыс. курганов, главным образом, в Керчи, Херсонесе, Ольвии и близ имения Смелы Черкасского уезда Киевской губ. Участвуя в раскопках кургана Солоха, нашел знаменитый золотой гребень, ныне хранящийся в Золотой кладовой Эрмитажа. В 1918 г. командирован РГАК на юг России, в 1919 г. эмигрировал из Одессы. Умер в Грассе, похоронен в Ницце (Тункина 2017).

11 Медведева, Всевиов, Мусин, Тихонов 2009, 140.
} 
атрибуции и аннотирования античных надписей. На основе собранных материалов был опубликован свод античных надписей Inscriptiones antiquae Orae Septentrionalis Ponti Euxini graecae et latinae (IOSPE), выходивший в первом издании с 1885 по 1901 гг. ${ }^{12}$. Очевидно, что при составлении труда столь обширного объема B.В. Латышев не мог лично контролировать поступление всех новых надписей, поэтому сведения о новых находках на территории Северного Причерноморья и Херсонеса поступали к нему от А.А. Бобринского. Письма к В.В.Латышеву от этих корреспондентов содержат десятки копий с античных надписей (эстампажи, фотографии, копии) со сведениями о местах их находок и хранения ${ }^{13}$.

11 апреля 1891 г. А.А. Бобринский, находясь на даче в Ялте, сообщает В.В. Латышеву об открытии важнейшего эпиграфического памятника - присяги граждан Херсонеса (IOSPE. Vol. I. № 401). Согласно его описаниям «она была обнаружена к западу от нового, достраивающегося храма. Сверху украшение в виде расплывшегося треугольника. Надпись я в Петербурге при помощи словарей разобрал. Она очень интересна и вероятно представляет формулу присяги, приносимой при вступлении в должность в Херсонесе или при поступлении в число горожан» ${ }^{14}$. Копию надписи А.А. Бобринский отправляет отдельно тем же письмом (рис. 1). Также он сообщает В.В. Латышеву об открытии новых херсонесских мозаик: «не знаю, видели ли Вы в Херсонесе открытие последнего года - мозаичные полы с изображением птиц. Я впервые нынче увидел эти великолепные памятники раннего христианского искусства и пришел в восхищение!» ${ }^{15}$. В письме от 19 мая 1891 г. А.А. Бобринский, отвечая на просьбу В.В. Латышева отправить ему эстампажи надписей из Херсонеса, пишет: «немедленно дал распоряжение об отправке Вам херсонесских надписей» ${ }^{16}$. К этому письму также приложен список с копиями эпиграфических памятников, продающихся в Керчи, с просьбой написать, «какие камни необходимы к немедленному приобретению». В следующем письме А.А. Бобринский отмечает, что «все надписи, о коих я Вам писал в последнем письме приобретены мной для Археологической комиссии (удалось их сторговать сравнительно недорого) и перевезены в Царский курган» ${ }^{17}$. Здесь же А.А. Бобринский упоминает о назначении нового директора Керченского музея: «В Керчи с 20 числа сего месяца новый директор, бывший учитель истории Ревельской гимназии, Карл Евгеньевич Думберг ${ }^{18}$. Я буду проездом в Керчи и попрошу у него

12 Первый том IOSPE включал 245 надписей, обнаруженных в районе между дельтой Дуная и Южным Крымом (Тира, Ольвия, Херсонес, Неаполь, Ай-Тодор). Второй том, выпущенный в 1890 г., содержал в себе 509 надписей Боспорского царства, как и третий (1901), в котором публиковались находки 1885-1900 гг. Третий том, в котором предполагалась публикация свода керамических клейм и граффити, порученный к изданию Е.М. Придику, опубликован не был. Вскоре началась публикация второго издания выпущенных томов, обусловленная множеством новых находок. Второе издание первого тома вышло в 1916 г., выпуск второго тома был прерван событиями Октябрьской революции.

13 Тункина 1999, 192.

14 СПбФ АРАН. Ф. 110. Оп. 2. Д. 5. Л. 15 об.

15 СПбФ АРАН. Ф. 110. Оп. 2. Д. 5. Л. 15 об.

16 СПбФ АРАН. Ф. 110. ОП. 2. Д. 5Л. 4 об.

17 СПбФ АРАН. Ф. 110. Оп. 2. Д. 5. Л. 9 об.

18 Думберг Кирилл (Карл) Евгеньевич (1862-1931) - археолог, заведующий Керченским музеем древностей (с 1891), член Императорской археологической комиссии (с 1891). В 1896-1899 гг. им были проведены масштабные и планомерные раскопки акрополя Пантикапея (Медведева, Всевиов, Мусин, Тихонов 2009, с. 171). 


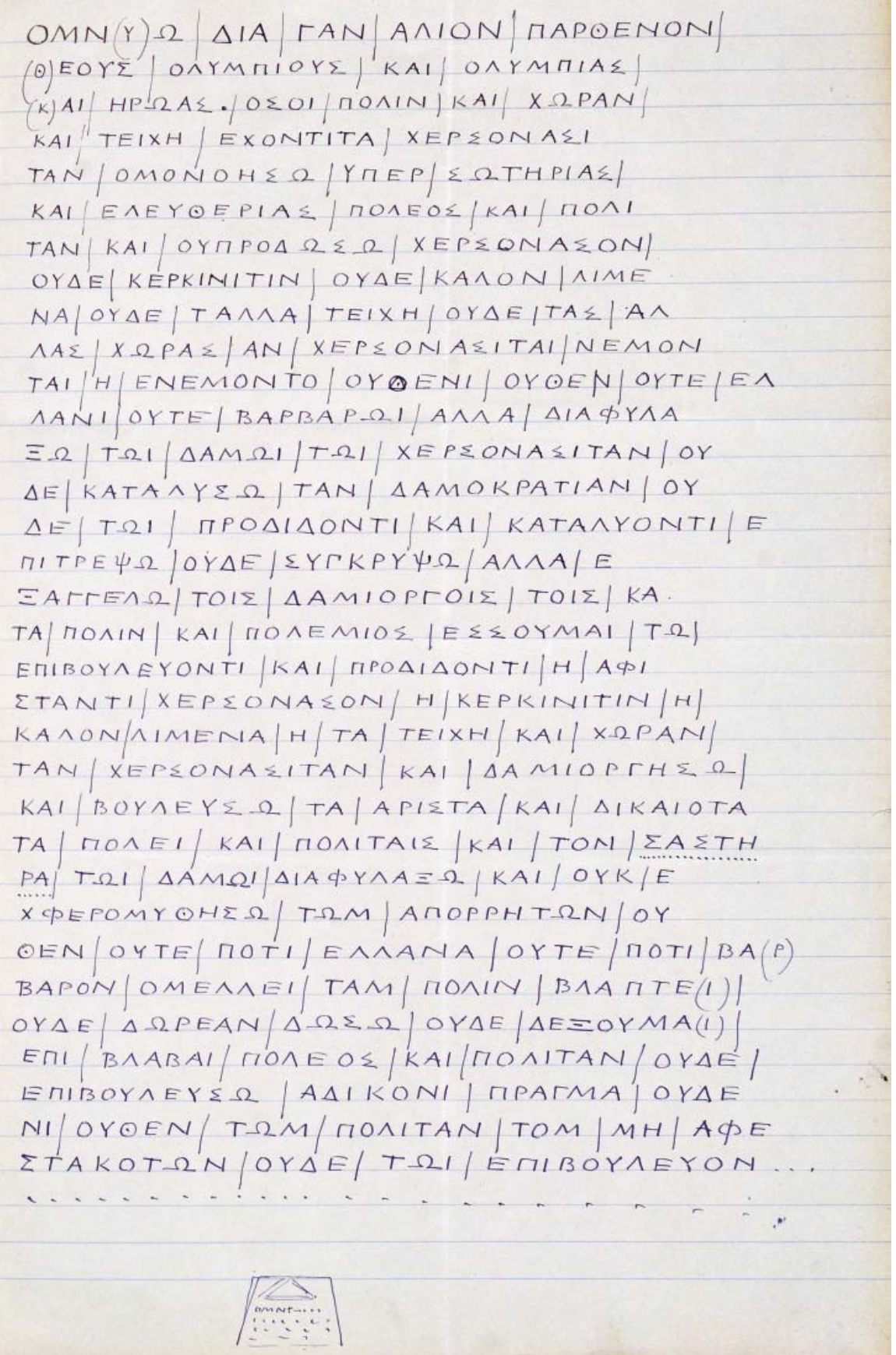

Рис. 1. Копия надписи присяги граждан Херсонеса

Fig. 1. Copy of the inscription of the oath of citizens of Chersonesos 
по возможности снять и послать Вам эстампажи новоприобретенных камней» ${ }^{19}$. Список новых античных надписей из Керчи также прилагается к письму вместе с упоминанием о мастерстве в их исполнении копий «учителя гимназии В.В. Шкорпила». В этом же письме А.А. Бобринский упоминает и о предмете из коллекции известного керченского коллекционера А. Новикова, видимо, заинтересовавшем его: «обещал мне Новиков снять фотографический снимок, который по получении пошлю Вам. Предмет очень курьезный» ${ }^{20}$.

В августе 1892 г. $^{21}$ В.В. Латышев в письме к А.А. Бобринскому просил поручить директору Керченского музея К.Е. Думбергу переслать ему копии с клейм, находящихся в музее, для устранения неточностей. Изготовление копий с амфорных и черепичных клейм предполагалось выполнять по методике, применяемой К.К. Косцюшко-Валюжиничем. В своем письме К.Е. Думбергу он подробно описал методику изготовления эстампажей 22 . К.Е. Думберг, однако, не был полностью уверен в эффективности этого метода, считая, что данная технология оправдывает себя только в случае хорошей сохранности памятника. К.Е. Думберг запрашивал в ИАК средства на изготовление слепков при помощи гипса, после чего было выделено 300 руб. на устройство гальванопластической мастерской. В последующих письмах К.Е. Думберга В.В. Латышеву за 1892-1899 гг. достаточно подробно описывается как выполняемый им процесс по изготовлению копий, так и много других проблем, связанных с античной эпиграфикой.

Первое письмо В.В. Латышеву, отложившееся в фонде, датируется 11 декабря 1892 г. В нем К.Е. Думберг отвечает, видимо, на просьбы В.В. Латышева об изготовлении эстампажей с памятников: «В настоящее время у нас очень сыро, так что нельзя сделать хороший эстампаж с плит, хранящихся в открытых зданиях» ${ }^{23}$. Относительно изготовления слепков с амфорных ручек он сообщал следующее: «со всех неизданных ручек я Вам представлю снимки и кроме того сообщу все наблюдения касательно материала, т.е. глины и пр.» ${ }^{24}$

После изготовления копий, эстампажи отправлялись К.Е. Думбергом в СанктПетербург в специальных деревянных ящиках. Судя по всему, после знакомства с научными работами В.В. Латышева и личной переписки К.Е. Думберг не мог не проникнуться глубоким уважением к его уровню профессионализма и глубины знания античной эпиграфики. Так, в одном из своих писем он просит ученого отправить ему фотопортрет: «Я не имею счастья Вас лично знать, но с тех пор как я познакомился в Дерпте с первым томом Ваших Inscriptiones, я питаю к Вам глубокое и подлинное уважение и мне хотелось бы иметь в своей комнате фотографию человека, который так много и образцово работает для истории греческих колоний» 25 .

19 СПбФ АРАН. Ф. 110. Оп. 2. Д. 5. Л. 10.

20 СПбФ АРАН. Ф. 110. Оп. 2. Д. 5. Л. 10. Речь идет о керамической игрушке в виде повозки. Подробнее см. ниже.

21 Три тома Inscriptiones antiquae Orae Septentrionalis Ponti Euxini graecae et latinae (IOSPE), выходившие в первом издании с 1885 по 1901 гг. содержали в себе корпус эпиграфических памятников Северного Причерноморья.

22 Федосеев 2017, 125.

23 СПбФ АРАН. Ф. 110. Оп. 2. Д. 19. Л. 1 об.

24 СПбФ АРАН. Ф. 110. Оп. 2. Д. 10.

25 СПбФ АРАН. Ф. 110. Оп. 2. Д. 19. Л. 11. 


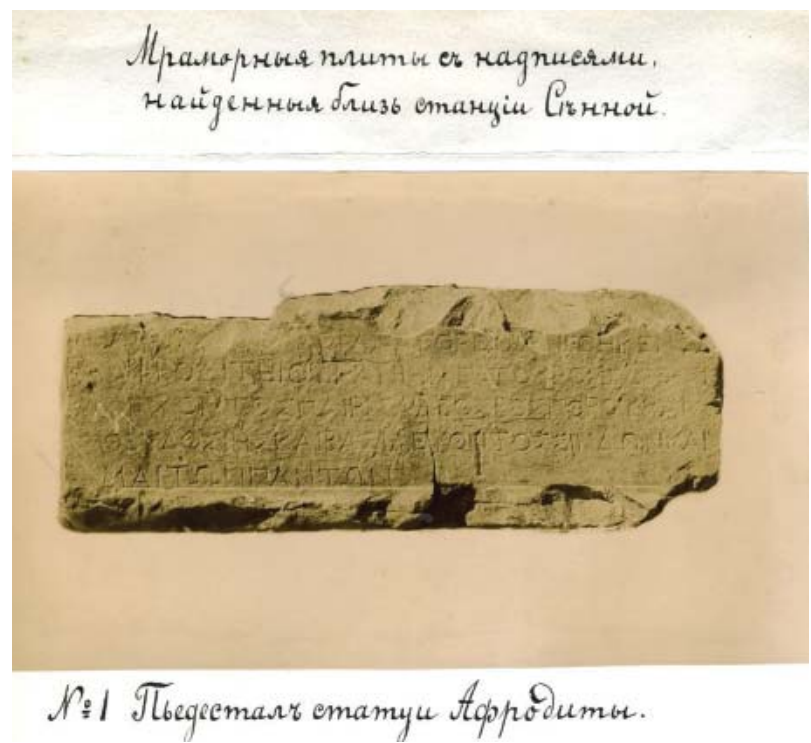

Рис. 2. Посвятительная надпись Аполлондора

Fig. 2. The commemorative inscription of Apollondor

В своих письмах К.Е. Думберг характеризовал процесс снятия негативов и эстампажей с надписей, отмечая, что «разница между осенним и зимним освещением разительная: в октябре из 44 негативов один оказался плохой, а теперь из 14 - 10 неудачных», замечая также, что «аристотипная бумага передает надписи гораздо лучше альбуминной» ${ }^{26}$. Эстампажи снимались совместно с В.В. Шкорпилом, преимущественно в хорошую погоду, поскольку эпиграфические памятники хранились в лапидариях Мелек-Чесменского и Царского курганов ${ }^{27}$. Зачастую К.Е. Думберг сетовал на то, что не может сразу найти требуемое надгробие, так как оно оказывалось заложено другими плитами и требовались существенные усилия для его извлечения ${ }^{28}$. Методика проверки качества эстампажей и исключения ошибок описывается К.Е. Думбергом в качестве подтверждения тому, почему снятие копий в зимнее время проблематично: «лежать в такую погоду по целым часам на камне и ломать себе голову над одной или другой буквой - это не особенно приятно, я, к сожалению, homo sum. Это покорнейше прошу принять во внимание, если найдете погрешности и глупости» ${ }^{29}$.

Продолжалась также работа и по изготовлению слепков с керамических клейм. В письме от 19 марта 1893 г. К.Е. Думберг сообщал о просьбе ИАК отправить дублетные экземпляры клейменных амфорных ручек в археологический музей при Казанском университете. При этом он сетовал на отсутствие необходимого финансирования ИАК на приобретение гипсовой массы, необходимой для изготовления слепков, обещая вместе с тем заказать все необходимое из Варшавы

\footnotetext{
26 СПбФ АРАН. Ф. 110. ОП. 2. Д. 19. Л. 11 об.

27 СПбФ АРАН. Ф. 110. Оп. 2. Д. 19. Л. 18.

28 СПбФ АРАН. Ф. 110. Оп. 2. Д. 19. Л. 48.

29 СПбФ АРАН. Ф. 110. Оп. 2. Д. 19. Л. 26.
} 
«на свой счет» и приступить к работе ${ }^{30}$. Несмотря на это К.Е. Думберг особо отмечает медленно продвигающуюся работу по изготовлению оттисков с амфорных ручек, отмечая что «Казанский университет может еще подождать, за что он больше от меня и получит».

11 сентября 1896 г. в письме, которое было отправлено во время проведения раскопок на территории Фанагории, К.Е. Думберг сообщал о находке двух статуй: одной - времени Перисада I и другой - императора Августа. Первая свидетельствует о посвящении статуи Афродите Апатуре и интересна тем, что в ней встречается имя Фанагора, другая посвящена Динамией императрице Ливии, что также не лишено интереса. Находка была сделана к юго-западу от станции Сенной, на территории Западного некрополя Фанагории. К.Е. Думбергом была обнаружена могила, перекрытием которой служили два постамента от статуй с надписью. На одном из постаментов и была выбита посвятительная надпись Аполлодора, сына Фанагора, Афродите Урании (КБН, № 971) (рис. 2). Первый раз на территории памятника был обнаружен эпиграфический памятник, в котором упоминается некий житель Фанагории, названный так вероятно в честь основателя города. Постамент датируется временем правления Перисада I (344-310 гг. до н.э.), на что прямо указывается в тексте надписи. Надпись на другом постаменте гласила, что царицей Динамией было поставлено изображение «своей благодетельницы» - супруги Августа Ливии (КБН, № 978). Надпись относится ко времени правления Динамии, т.е. к концу I в. до н.э. Любопытно, что два этих разновременных постамента закрывали одну гробницу. К.Е. Думберг не приводит описания этой гробницы, но, скорее всего, она принадлежала ко времени поздней античности. Здесь же была найдена часть известняковой статуи в виде молодого воина в панцире и с оружием (рис. 3).

Помимо вопросов античной эпиграфики, в 1898 г. К.Е. Думберг обращался к В.В. Латышеву с просьбой подготовить исторический очерк, посвященный истории Боспорского царства с IV в. до н.э. и до средневекового периода, для размещения этой работы в ежегоднике Керченского градоначальства.

Интересно отметить, что в письме от 9 сентября 1894 г. К.Е. Думберг отправил В.В. Латышеву фото керамической повозки, речь о которой шла ранее в письме А.А. Бобринского: «Профессор Кулаковский сообщил, что Вы желаете иметь фотографию глиняной повозки из коллекции Новикова. Посылаю Вам один экземпляр $»^{31}$ (рис. 4).

Сохранившиеся в СПбФ АРАН письма В.В. Шкорпила ${ }^{32}$, датируются с 6 октября 1896 по 6 января 1910 г. В них он не менее подробно сообщал В.В. Латышеву

30 Обратился он также с просьбой поспособствовать устройству на должность учительницы рисования в Казанский университет «барышни Юлии Васильевой, окончившей курс рисования и черчения в Штиглицком училище в Петербурге» и выполнившей для ИАК несколько работ, в том числе «срисовавшей катакомбу Сорака и несколько надгробных плит».

31 СПбФ АРАН. Ф. 110. Оп. 2. Д. 19. Л. 13 об.

32 Шкорпил Владислав Вячеславович (1853-1918) - археолог, эпиграфист; действительный член ООИД (1894), ТУАК (1903), член Императорской археологической комиссии - РГАК (19011918), Германского археологического института, Общества чешских филологов, Варненского археологического общества. Учитель древних языков Александровской прогимназии в Ялте (1878-1886) и в Александровской гимназии в Керчи (1886-1903), заведующий Мелек-Чесменским курганом, находящимся в ведении ООИД (с 1894), директор Керченского музея древностей (1901-1918). Командирован ИАК в Грецию по приглашению В. Дерпфельда от Афинского отделения Германского 


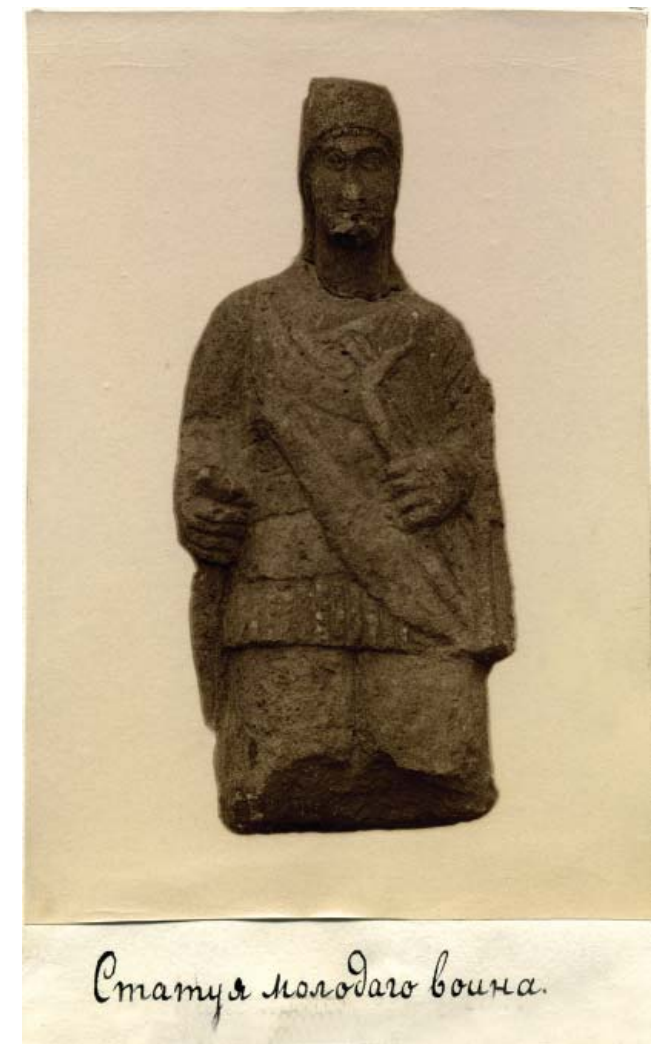

Рис. 3. Часть известняковой статуи молодого воина

Fig. 3. Part of the limestone statue of the young warrior

о ежегодных находках эпиграфических памятников и приобретениях экспонатов от коллекционера А.В. Новикова для Керченского музея древностей, а также отправлял описи с фотографиями и эстампажами. Сообщал он также и о неточностях в рисунках надписей, которые были выполнены ранее Ф.И. Гроссом. Кроме того, в одном из писем присутствует крайне важная информация, полученная в ходе работы В.В. Шкорпила с полевым дневником К.Р. Бегичева ${ }^{33}$. Как он пишет, «в рукописном журнале Бегичева о раскопках 1851-1856 гг. на задней странице, среди заметок о рабочих и плате, выдаваемой им, сохранилась копия надписи, изданной в IOSPE № 370, с припиской: «Надпись на камне, открытом на восточном берегу Керченского пролива напротив Горелой могилы в 1847 году» ${ }^{34}$. Согласно данным журнала после открытия этой надписи К.Р. Бе-

археологического института (1904). Заведующий раскопками в Херсонесе (июль - декабрь 1914). В декабре 1918 г. убит грабителями в подъезде собственного дома.

33 Рукописный дневник К.Р. Бегичева, содержащий информацию о раскопках в Керчи и на Таманском полуострове в 1851-1856 гг., долгое время считался утерянным в ходе эвакуации архива Керченского музея в Армавир в 1942 г. Несколько лет назад он был выявлен среди рукописных бумаг Н.В. Быковской и готовится в настоящее время к публикации. Машинописная копия фрагмента дневника, выполненная в 1927-1928 гг., хранится в ОПИ ГИМ.

34 СПбФ АРАН. Ф. 110. Оп.2. Д. 66. Л. 78. 


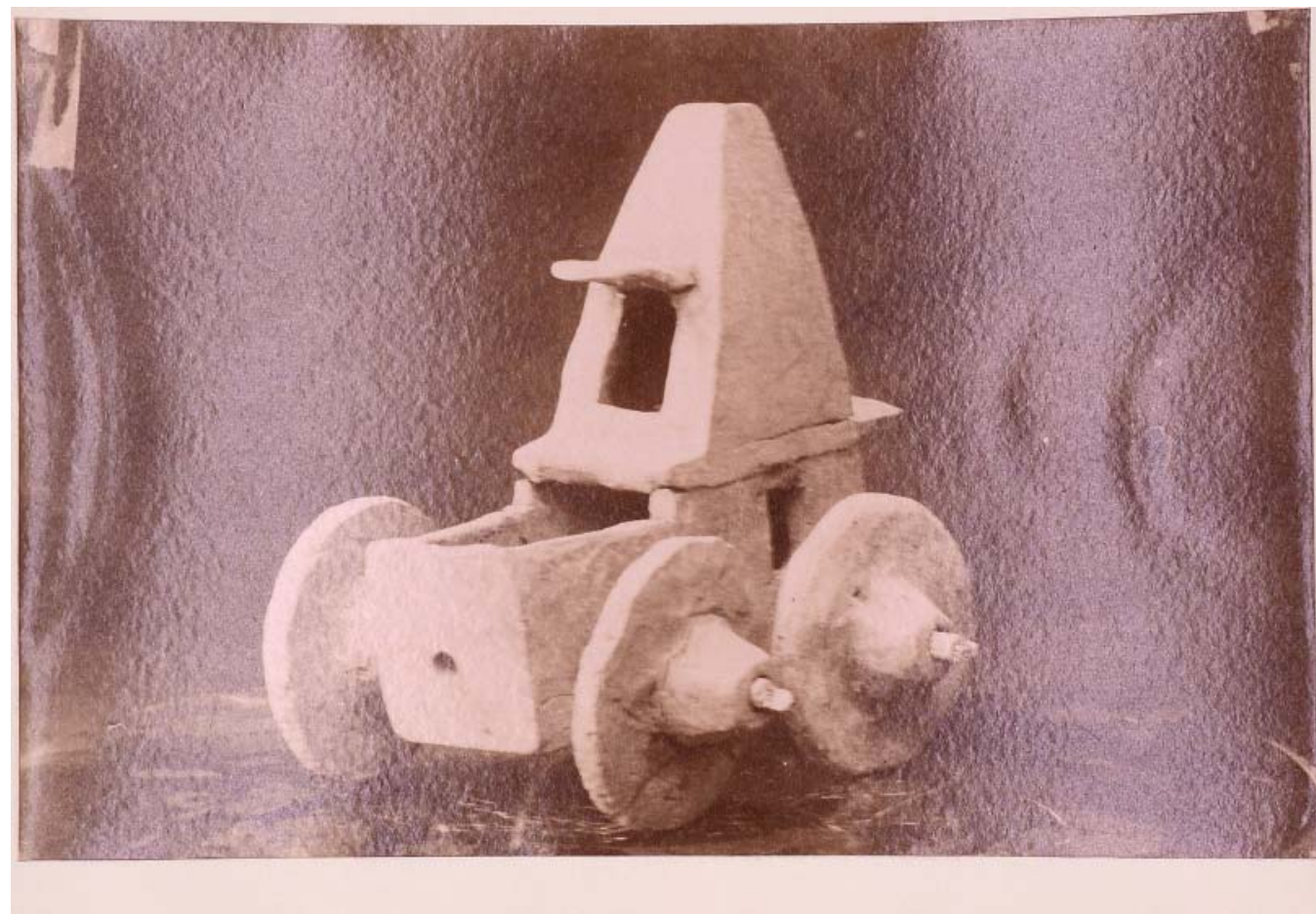

Рис. 4. Фотография глиняной повозки из коллекции Новикова Fig. 4. Photo of a clay wagon from the Novikov collection

гичевым была подана докладная записка на имя 3.С. Херхеулидзева о находке в Тамани камня с надписью. По распоряжению градоначальника К.Р. Бегичеву предписывалось отправиться в Тамань, осмотреть находку и доставить ее в Музей, а также произвести, если потребуется, раскопки на месте находки. В рапорте К.Р. Бегичева от 28 февраля 1847 г. упоминается о проведенных раскопках близ хутора Чумаченко в 40 верстах от Тамани, но сама плита с надписью в Керчь не была доставлена по причине «дорог, совершенно испорченных ненастьем» ${ }^{35}$.

Помимо сведений о находках эпиграфических памятников, В.В. Шкорпил сообщал и о проводимых археологических раскопках и находках. Так, в письме от 20 марта 1905 г. содержатся сведения об открытии на склоне горы Митридат римского некрополя I в. н.э. (женские гробницы со стеклянными и краснолаковыми сосудами), а в письме от 23 марта 1906 г. - о находке свинцовой таблички с проклятиями в одной из жженых гробниц на втором склоне горы Митридат ${ }^{36}$. В связи с этим неоднократно в письмах В.В. Шкорпил обращал внимание В.В. Латышева на то, что часто препятствием к археологическим раскопкам являются местные жители: «неужели наука должна зависеть от каприза полуграмотных людей и от алчности

\footnotetext{
35 СПбФ АРАН. Ф. 110. Оп.2. Д. 66. Л. 78.

36 СПбФ АРАН. Ф. 110. Оп.2. Д. 66. Л. 50.
} 
торгашей, и неужели те, которые охраняют интересы археологии и ее отраслей, не имеют никакой возможности сделать достоянием науки то, что найдено?» ${ }^{37}$.

Множество эпиграфических надписей, которые не вошли в свод надписей В.В. Латышев опубликовал в виде поправок и дополнений в «Записках» РАО или же в отдельных изданиях ИАК ${ }^{38}$. Кроме того, в результате изучения рассмотренных выше писем можно выявить множество интересных деталей, касающихся организации и проведения археологических раскопок на Керченском и Таманском полуостровах, а также изучения и атрибуции археологического материала. Сравнив полученные данные с трудами современных исследователей, посвященных истории развития керамической эпиграфики в Российской империи ${ }^{39}$, можно проследить эволюцию методологии и методики в изучении этих групп археологического материала.

\section{ЛИТЕРАТУРА}

Тункина, И.В. 1999: В.В. Латышев: жизнь и ученые труды. В кн.: А.П. Медведева (ред.), Рукописное наследие русских византинистов в архивах Санкт-Петербурга. СПб., $172-288$.

Тункина, И.В. 2002: Русская наука о классических древностях юга России (XVIII - середина XIX в.). СПб.

Тункина, И.В. 2017: Биоблиографический словарь членов РАО (1846-1924). В кн.: С.А. Жебелев (ред.), Русское археологическое общество за третью четверть века своего существования 1897-1921. Исторический очерк. М.

Федосеев, Н.Ф. 2017: Греки на Боспоре Киммерийском: 200 лет исследований. Симферополь.

\section{REFERENCES}

Fedoseev, N.F.2017: Greki na Bospore Kimmeriiskom: 200 let issledovanii [The Greeks of the Cimmerian Bosporus: 200 years of research]. Simferopol.

Tunkina, I.V. 1999: V.V. Latyshev: zhizn' i uchenye trudy [V.V. Latyshev: the life and the works]. In: A.P. Medvedeva (ed.), Rukopisnoe nasledie russkikh vizantinistov v arkhivakh Sankt-Peterburga [Handwritten heritage of Russian byzantinists in the archives of St. Petersburg]. Saint Petersburg.

Tunkina, I.V. 2017: Biobibliograficheskiy slovar' chlenov RAO (1846-1924) [Biobibliographical glossary of members of the Russian Archaeological Society]. In: S.A. Zhebelev (ed.), Russkoe arkheologicheskoe obshchestvo za tret'yu chetvert'veka svoego sushchestvovaniya. 1897-1921. Istoricheskiy ocherk [The Russian Archaeological Society during the third quarter of a century of its activities. A historical essai]. Moscow.

Tunkina, I.V. 2002: Russkaya nauka o klassicheskikh drevnostyakh yuga Rossii [Russian science of classical antiquities of the South of Russia]. Saint Petersburg.

\footnotetext{
37 СПбФ АРАН. Ф. 110. Оп.2. Д.66. Л. 53.

38 Тункина 1999, 189.

39 Тункина 2002.
} 


\title{
A.A. BOBRINSKY, K.E. DUMBERG AND V.V. SHKORPIL'S LETTERS TO V.V. LATYSHEV (IN THE ST. PETERSBURG BRANCH OF THE ARCHIVE OF THE RUSSIAN ACADEMY OF SCIENCES)
}

\author{
Evgenia G. Zastrozhnova
}

Saint Petersburg Branch of Archive of Russian Academy Science, Saint Petersburg, Russia pankratova0484@yandex.ru

Abstract. The paper deals with the letters of A.A. Bobrinsky, the chairman of the Imperial Archaeological Commission, and K.E. Dumberg and V.V. Shkorpil, the directors of the Kerch Museum of antiquities, written to V.V. Latyshev. These documents are concerning various issues of discoveries, acquisitions, interpretation and study of the epigraphy found in the south of the Russian Empire in 1892-1910. Through analysis of this valuable source, it becomes possible to find previously unknown details of the organization and conduct of archaeological excavations in the North Black Sea Region, and to trace the sources of archaeological collections, as well as to identify features of the research and methodical work with such category of archaeological finds, as epigraphic monuments and ceramic stamps.

Keywords: epigraphy, Bosporan Kingdom, history of archaeological study, V.V. Latyshev, history of science, archival documents 